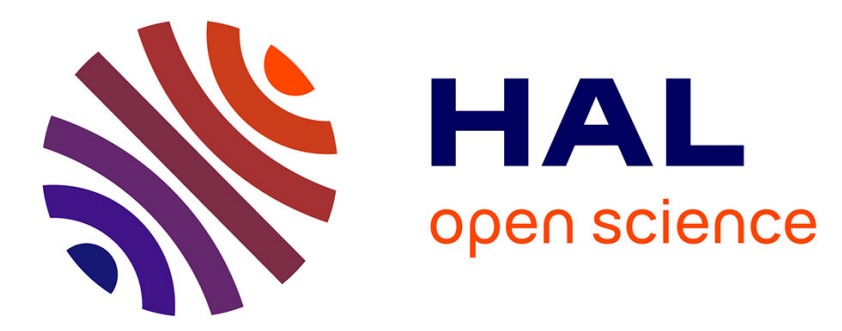

\title{
THE SPECIFICITY OF PLASMA GENERATION WITH LASER IRRADIATION OF METALS IN CRYOGENIC LIQUIDS
}

S. Astapchik, T. Khatko

\section{- To cite this version:}

S. Astapchik, T. Khatko. THE SPECIFICITY OF PLASMA GENERATION WITH LASER IRRADIATION OF METALS IN CRYOGENIC LIQUIDS. Journal de Physique IV Proceedings, 1991, 01 (C7), pp.C7-187-C7-187. 10.1051/jp4:1991749 . jpa-00250991

\section{HAL Id: jpa-00250991 https://hal.science/jpa-00250991}

Submitted on 1 Jan 1991

HAL is a multi-disciplinary open access archive for the deposit and dissemination of scientific research documents, whether they are published or not. The documents may come from teaching and research institutions in France or abroad, or from public or private research centers.
L'archive ouverte pluridisciplinaire HAL, est destinée au dépôt et à la diffusion de documents scientifiques de niveau recherche, publiés ou non, émanant des établissements d'enseignement et de recherche français ou étrangers, des laboratoires publics ou privés. 


\section{THE SPECIFICITY OF PLASMA GENERATION WITH LASER IRRADIATION OF METALS IN CRYOGENIC LIQUIDS}

S.A. ASTAPCHIK and T.N. KHATKO

Physical and Engineering Institute of Academy of Sciences of BSSR, Zhodinskaya 4, Minsk 220730, USSR

The spectral analysis and photorecording have been conducted to study the specific features of plasma generation in case of laser irradiation of metallic targets placed in cryogenic liquids. Metals were irradiated in liquid nitrogen and oxygen. Specific flux of laser irradiation $(\lambda=1.06 \mu \mathrm{m} ; \tau=1-6 \mathrm{~ms}$ and $1 \mu \mathrm{s})$ varies from $10^{4}$ to $10^{9} \mathrm{~W} \cdot \mathrm{cm}^{-2}$. Flames spectra were recorded by a quartz spectrograph. A threshold of optical break-down of metal vapors or a molecular gas was established by occurrence of ion lines in the spectra. Simultaneously with spectra recording,flames and plasma generations were photorecorded. It is shown that when laser irradiation gets onto a metallic target surface beneath a cryogenic liquid layer there occurs local explosive evaporation and formation of a highpressure region. Its value is estimated as $1.0 \mathrm{GPa}$. Hxperiments performed for comparison in air at a target temperature of $293 \mathrm{~K}$ have shown that when a metal surface attains on evaporation temperature, there forms an erosion flame. A further increase of laser irradiation intensity causes optical break-down of vapors. When metals are irradiated beneath the cryogenic liquid layer, erosion flames are not produced and the optical break-down of vapors develops at laser irradiation power density considerably less than that. in case of irradiation in air. Thus, the existence of high-pressure region when targets are laser-irradiated beneath a cryogenic liquid layer results in supression of the metal evaporation process and a decrease of the optical break-down threshold. 